\title{
ВИКОРИСТАННЯ ВІДЕОКОНФЕРЕНЩЇ У КРИМІНАЛЬНОМУ ПРОВАДЖЕННІ УКРАЇНИ ТА СФЕРІ МІЖНАРОДНОГО СПІВРОБІТНИЦТВА ДЕРЖАВ У КРИМІНАЛЬНОМУ СУДОЧИНСТВІ
}

\author{
USING VIDEOCONFERENCING IN CRIMINAL PROCEEDINGS OF UKRAINE \\ AND THE AREA OF INTERNATIONAL COOPERATION \\ AMONG THE STATES IN CRIMINAL JUSTICE ARE EXAMINED
}

\author{
Смирнов М.I., к.ю.н., доцент, \\ доцент кафедри кримінального процесу, детективної \\ та оперативно-розшукової діяльності \\ Національний університет «Одеська юридична академія»
}

\begin{abstract}
У статті розглядаються окремі дискусійні питання, пов'язані з особливостями використання відеоконференції в кримінальному провадженні в цілому та на окремих його стадіях, а також обґрунтовуються власні висновки та пропозиції, спрямовані на подальше вдосконалення кримінального процесуального законодавства України в частині розглянутих питань.

Досліджено сутність, значення, переваги, сучасний стан та перспективи використання відеоконференції в кримінальному провадженні України та сфері міжнародного співробітництва держав у кримінальному судочинстві.

Проаналізовано стан правового регулювання використання відеоконференції в кримінальному провадженні. Кримінальний процесуальний кодекс України передбачає використання відеоконференції як у кримінальному провадженні України, так і у кримінальних провадженнях ускладнених іноземним елементом.

Проаналізовано підстави, процесуальний порядок та сформульовано особливості використання відеоконференції в кримінальному провадженні України та сфері міжнародного співробітництва держав у кримінальному судочинстві.

Відеоконференція може застосовуватися за рішенням слідчого, прокурора, слідчого судді або суду в кожному конкретному випадку з урахуванням обставин кримінального провадження та наявності підстав, передбачених Кримінальним процесуальним кодексом України.

Перед початком проведення слідчої (розшукової) дії або судового засідання за допомогою відеоконференції необхідно переконатися, що ніщо не перешкоджає особі вільно давати свідчення, заявляти клопотання, надавати докази тощо. Ця обставина має суттєве значення для допустимого використання в кримінальному провадженні доказів, отриманих за допомогою відеоконференції.

Проведення запитуваних процесуальних дій шляхом відеоконференції дає обвинувачуваному, потерпілому та іншим учасникам можливість під час досудового розслідування або судового розгляду (за умови дотримання змагальності) висловлюватися з розглянутих питань, наводити доводи для спростування висновків протилежної сторони, надавати докази та заявляти клопотання.

Сформульовано особливості проведення допиту за допомогою відеоконференції у сфері міжнародної правової допомоги, а також переваги одержання свідчень від осіб, які тримаються під вартою або відбувають покарання в іноземній державі, за допомогою відеоконференції порівняно з традиційними способами їх одержання.

Розглянуто питання про співвідношення відеоконференції із засадами кримінального провадження та доведено, що застосування відеоконференції цілком узгоджується із засадами кримінального провадження. Відеоконференція є однією з процесуальних форм використання інформаційних технологій у кримінальному провадженні та використовується для позначення заходу, учасники якого територіально віддалені один від одного, тому спілкування між ними відбувається з використанням технічних засобів зв'язку, що забезпечують передання зображення і звуку в режимі реального часу.
\end{abstract}

Ключові слова: відеоконференція в кримінальному провадженні, допит шляхом проведення відеоконференції, процесуальний порядок та особливості використання відеоконференції.

The article deals with specific controversial issues concerning features of using videoconferencing in criminal proceedings in general as well as at its specific stages; also own conclusions and propositions are justified which are aimed at further development of criminal procedural legislation of Ukraine with the regard to the questions raised.

The essence, meaning, advantages, current state, and perspectives of using videoconferencing in criminal proceedings of Ukraine and the area of international cooperation among the states in criminal justice are examined.

The state of legal regulation of using videoconferencing in criminal proceedings is analyzed. Code of Criminal Procedure of Ukraine provides for using videoconferencing both in criminal proceedings of Ukraine and criminal proceedings with a foreign element.

Based on the analysis of grounds and procedure of video-conferencing features of its usage both in criminal proceedings of Ukraine and in the area of international cooperation among the states in criminal justice are identified.

Videoconferencing can be used based on the decision of an investigator, prosecutor, investigative judge, or court in each case taking into account circumstances of criminal proceedings and subject to grounds provided for by the Code of Criminal Procedure of Ukraine.

Before the start of investigative (search) action or court session using video-conferencing one shall ensure that nothing prevents a person from giving testimony, making motions, providing evidence, etc. This fact is essential for the admissibility of evidence used in criminal proceedings obtained using videoconferencing.

Conducting requested procedural actions by video-conferencing ensure that an accused person, a victim, and other participants have an opportunity to express themselves on the raised issues, make arguments aimed to rebut the conclusions of the opposing party, provide evidence and make motions during pre-trial investigation or trial.

Specificities of conducting a questioning using videoconferencing in the area of international cooperation as well as advantages of obtaining testimony from individuals put into custody or serving a sentence in a foreign state using video-conferencing compared to traditional means are formulated.

The issue of interrelation between videoconferencing and principles of criminal proceedings is examined and it is showed that using videoconferencing is fully consistent with principles of criminal proceedings. Videoconferencing is one of the procedural forms of using information technologies in criminal proceedings and is used to conduct an action, participants of which are geographically separated one from another and thus communication among them are conducted using the communication technologies that support real-time image and voice transmission.

Key words: videoconferencing in criminal proceedings; questioning by having a videoconference; procedure and features of using videoconferencing. 
Постановка проблеми. Використання відеоконференції (далі - ВК) у кримінальному провадженні України хоча і становить значний теоретичний та практичний інтерес, однак усе-таки належить до розряду недостатньо досліджених наукових проблем. Проблема застосування ВК у кримінальному провадженні комплексна та має фінансову, організаційну, технічну, правову, процесуальну і навіть психологічну сторони.

Крім того, недостатність досвіду застосування ВК у кримінальному провадженні в цілому та на окремих його стадіях (а іноді й заперечення такого використання 3 боку практичних працівників) негативно позначається на ефективності iii застосування. Ще однією причиною такого стану є відсутність фундаментальних теоретичних розробок щодо використання інформаційних технологій у кримінальному провадженні, зокрема таких, як ВК. Унаслідок цього багато актуальних питань використання ВК залишаються ще не вирішеними на законодавчому рівні. Цей факт міг би залишитися простою констатацією, якби не перспектива використання розглянутої технології в кримінальному провадженні України.

Стан дослідження. Питання, пов'язані з особливостями використання ВК у кримінальному провадженні в цілому та на окремих його стадіях, у кримінальних провадженнях, ускладнених іноземним елементом, перебували в центрі уваги науковців та практиків. Щодо цього питання свою фахову позицію висловлювали Ю.П. Аленін, Т.С. Гавриш, І.В. Гловюк, В.Т. Маляренко, М.І. Пашковський та інші.

Метою статті є розгляд окремих дискусійних питань, пов'язаних із особливостями використанням ВК у кримінальному провадженні, а також обгрунтування власних висновків та пропозиції, спрямованих на подальше вдосконалення кримінального процесуального законодавства України в частині розглянутих питань.

Виклад основного матеріалу дослідження. Використанню ВК у кримінальному провадженні України, присвячені ст. ст. 232, 336 та 567 Кримінального процесуального кодексу України (далі - КПК). Якщо ст. 567 КПК передбачає впровадження ВК у сферу міжнародної правової допомоги (проведення допиту за запитом компетентного органу іноземної держави шляхом ВК), то ст. ст. 232 та 336 КПК регламентують використання ВК у національному кримінальному провадженні, не ускладненому іноземним елементом. Так, КПК дозволяє проведення у режимі ВК таких дій: допиту осіб, зокрема й одночасного допиту двох чи більше вже допитаних осіб (очна ставка), пред'явлення для впізнання осіб та речей (пред'явлення для впізнання трупа в режимі ВК законом не передбачається), проведення процесуальних дій у режимі ВК під час судового провадження.

Відомо, що зміст та форма кримінального провадження повинні відповідати загальним засадам кримінального провадження. Слід зауважити, що більшість засад кримінального провадження взагалі «не відчувають» на собі впливу ВК і продовжують діяти так, як і за умов традиційного порядку проведення процесуальних, слідчих (розшукових) дій або судового провадження. Використання ВК у кримінальному провадженні незначно впливає лише на засаду безпосередності дослідження показань, речей і документів. Це зумовлено тим, що проведення процесуальних дій у режимі ВК має деякі особливості, зокрема, застосування ВК дозволяє учасникам «бути присутніми» під час проведення слідчої (розшукової) дії або судового засідання, не перебуваючи безпосередньо в приміщенні органу досудового розслідування, суду, використовуючи термінали, які розташовані в інших приміщеннях.

Однак факт перебування підозрюваного, потерпілого, свідка або іншої особи в приміщенні органу досудового розслідування, суду або іншому місці проведення процесуальної, слідчої (розшукової) дії суттєво не впливає на здатність слідчого, прокурора, слідчого судді, суду відрізняти правдиві показання від неправдивих. Слідчий, прокурор, слідчий суддя або суд, отримуючи показання шляхом ВК, може враховувати майже всі нюанси поведінки, які виявляються під час особистого спілкування, тому використання ВК не має суттєвих недоліків порівняно $з$ традиційними порядком проведення слідчих (розшукових) дій та не має кардинальних відмінностей в оцінці їх показань.

Підозрюваний, потерпілий, свідок та інші особи доступні слідчому, прокурору, слідчому судді або суду і можуть бути допитані за всіх обставин, що мають значення для кримінального провадження. Особа безпосередньо не перебуває в приміщенні органу досудового розслідування, суду, однак її віддалена присутність забезпечується ВК. Вона дає можливість заявляти клопотання, подавати докази, брати участь у їх дослідженні.

Отже, застосування ВК цілком узгоджується із засадами кримінального провадження, а сама ВК є процесуальною формою використання інформаційних технологій у кримінальному провадженні та використовується для позначення заходу, учасники якого територіально віддалені один від одного, тому спілкування між ними відбувається з використанням технічних засобів зв'язку, що забезпечують передання зображення і звуку в режимі реального часу.

Проведення слідчих (розшукових) дій у режимі ВК може застосовуватися за рішенням слідчого, прокурора, слідчого судді або суду в кожному конкретному випадку 3 урахуванням обставин кримінального провадження та наявності підстав, а саме: неможливості безпосередньої участі певних осіб у досудовому провадженні за станом здоров'я або з інших поважних причин; необхідності забезпечення безпеки осіб; проведення допиту малолітнього або неповнолітнього свідка, потерпілого; необхідності вжиття таких заходів для забезпечення оперативності досудового розслідування; наявності інших підстав, визначених слідчим, прокурором, слідчим суддею достатніми.

Наведений перелік не $є$ вичерпним, оскільки у п. 5 ч. 1 ст. 232 КПК, вказано на «наявність інших підстав, визначених слідчим, прокурором, слідчим суддею достатніми». Наявність хоча б однієї з названих обставин буде достатньою підставою для проведення слідчої (розшукової) дії в режимі ВК.

Аналогічні підстави, передбачені у ч. 1 ст. 232 КПК, зазначені у ч. 1 ст. 336 КПК щодо проведення судового провадження у режимі ВК.

Підставами проведення допиту за запитом компетентного органу іноземної держави шляхом ВК можуть бути: неможливість прибуття певних осіб до компетентного органу іноземної держави, необхідність забезпечення безпеки осіб, інші підстави, визначені слідчим суддею (судом).

Під «неможливістю прибуття певних осіб до компетентного органу іноземної держави» необхідно розуміти недоступність особи для надання свідчень, ії небажання прибути до органу досудового розслідування або суду запитуючої держави і добровільно дати показання, якщо на неї не поширюється обов'язок з'явитися за повісткою, направленою компетентним органом запитуючої держави, який здійснює кримінальне провадження. Особи, які не є громадянами запитуючої держави і перебувають на території іноземної держави, як правило, вважаються недоступними.

Неможливість особистої присутності особи в місці проведення допиту може бути зумовлена її хворобою, неміччю або іншими непереборними обставинами, що перешкоджають участі особи в проведенні процесуальної або слідчої (розшукової) дії, витратами, пов'язаними 3 явкою особи до місця проведення процесуальної або 
слідчої (розшукової) дії з урахуванням важливості iï показань.

Підставою для проведення допиту за допомогою ВК може бути необхідність забезпечення безпеки осіб. Слід зауважити, що проведення дистанційного допиту особи без змін зовнішності і голосу, за яких ії неможливо було б упізнати, що цілком виключає іiі ідентифікацію для інших учасників, досягти бажаного результату, а саме забезпечити безпеку особи, майже неможливо.

До «інших підстав, визначених слідчим суддею (судом)», можна зарахувати такі випадки: необхідність одержання і дослідження показань в умовах, що ускладнюють або виключають через причини об'єктивного i (або) суб'єктивного характеру присутність першоджерела доказів (обвинувачуваного, потерпілого, свідка, експерта та інших осіб) у місці їх одержання і дослідження протягом тривалого чи невизначеного періоду часу, тобто необхідність забезпечення віддаленої присутності учасників процесуальної дії, які перебувають в іноземній державі; необхідність одержання показань від осіб, що тримаються під вартою, засуджених і осіб, які відбувають покарання на території іноземної держави; наявність заявленого клопотання обвинувачуваного про виклик і допит свідка, що викриває його у вчинені кримінального правопорушення і який перебуває на території іноземної держави, тобто використання ВК як реального механізму реалізації права конфронтації; особлива важливість показань у кримінальному провадженні, ускладненому іноземним елементом, і неможливість або особлива складність їх одержання традиційним способом.

Застосування ВК розв'язує проблему явки зазначених у повістці осіб, оскільки санкції за ухилення від явки і давання свідомо неправдивих свідчень у країнах, які використовують ВК, поширені у такому разі, тому свідок, що ухиляється від явки чи дав свідомо неправдиві показання хоча формально своїми діями (бездіяльністю) перешкоджає іноземному кримінальному провадженню, однак притягується до відповідальності за законами країни, на території якої він давав показання, або від явки за повісткою до компетентних органів, якої він ухилявся.

Крім того, слід констатувати переваги одержання показань від осіб, які тримаються під вартою або відбувають покарання в іноземній державі, за допомогою ВК порівняно з традиційними способами їх одержання.

Так, альтернативою безпосередньої присутності особи, яка тримається під вартою або відбуває покарання на території іноземної держави, може бути іiі віддалена участь у допиті за допомогою ВК. У такому разі підстави для відмови у тимчасовому переданні особи, зазначені у Європейській конвенції про взаємну допомогу в кримінальних справах від 20.04.1959 р. [1], перестають мати імперативний характер.

Так, підставою для відмови у тимчасовому переданні особи, може бути необхідність їі присутності для кримінального провадження, що здійснюється на території запитуваної держави. Проведення допиту такої особи за допомогою ВК дає можливість фізично не передавати особу запитуючій державі, забезпечити іiї віддалену участь у проведенні допиту й забезпечити здійснення кримінального провадження на території запитуючої держави.

Відповідно до іншої підстави, в тимчасовому переданні особи може бути відмовлено, якщо це може привести до продовження строків іiї тримання під вартою. Використання ВК у такому разі буде допустимим компромісом, оскільки дозволяє проводити необхідні запитуючій державі за участю такої особи процесуальні дії в найкоротший строк, що має вагоме значення щодо дотримання строку тримання під вартою і мінімізації негативних наслідків тривалого кримінального провадження.

Прохання щодо тимчасового передання особи виконуються лише за згодою такої особи. Тому неотримання згоди від особи, тимчасового передання якої просить запитуюча держава, $є$ самостійною підставою для відмови у задоволенні заявленого прохання. Така відмова може бути викликана об'єктивними причинами, основними серед яких $\epsilon$ відсутність належних гарантій іiі особистої безпеки. Крім того, якщо стосовно такої особи до ії̈ передання запитуючій державі буде обрано запобіжний захід, не пов'язаний із їі триманням під вартою, то це унеможливлює виконання прохання про ії̈ тимчасове передання. Згода особи на проведення за іiі участю запитуваних процесуальних дій за допомогою ВК є необов'язковою, оскільки цим не порушується право особи на особисту недоторканність і свободу.

Необхідно звернути увагу на те, що за умов тимчасового передання особи у деяких випадках виникає проблема іiі транзиту через третю державу (коли між відповідними державами відсутні прямі шляхи сполучення), оскільки законодавством багатьох країн таких транзит не допускається. Звідси виникає неможливість тимчасового передання особи, що тримається під вартою на території іноземної держави, для проведення за ії участю процесуальних дій. Допит такої особи за допомогою ВК ефективно розв'язує і цю проблему. Потенційна економія в такому разі визначається вартістю витрат на охорону і транспортування.

Крім того, ВК вирішує проблему прохань двох і більше держав, що збігаються за часом стосовно тимчасового передання особи, яка тримається під вартою на території запитуваної держави, для проведення за її участю процесуальних дій. Одночасне задоволення прохань двох держав про тимчасове передання такої особи в межах чинної системи міжнародного співробітництва та правової допомоги буде неможливим. Безумовно, ухвалюючи рішення, запитувана держава враховує всі відповідні фактори і перевагу може віддати проханню держави, 3 якою має договірні відносини. Але може скластися ситуація, коли запитувана держава не пов'язана будь-якими договірними зобов'язаннями про тимчасове передання особи 3 жодною із запитуючих держав. Оптимальне вирішення зазначеної проблеми може бути знайдене за допомогою використання ВК, що дозволить забезпечити віддалену присутність особи перед компетентними органами запитуючих держав, забезпечивши їй віддалену участь у необхідних цим державам процесуальних діях. Отже, ВК надає можливість одночасного задоволення клопотань двох і більше держав про тимчасове передання особи, тим самим дозволяючи вирішити проблему прохань, що збігаються за часом.

ВК дозволяє вирішити ще одну проблему, коли держава, яка одержала прохання про тимчасове передання особи, одержує також прохання від іншої запитуючої держави про передання цієї особи, тобто коли особа одночасно є об'єктом кримінального переслідування в одній державі, а також необхідність іiі присутності для проведення процесуальних дій потрібна в іншій державі.

Частина 2 ст. 232 КПК передбачає, що рішення про проведення слідчої (розшукової) дії у режимі ВК ухвалюється слідчим, прокурором, слідчим суддею (в разі проведення у режимі ВК допиту згідно зі ст. 225 КПК) за власною ініціативою або за клопотанням сторони кримінального провадження чи інших учасників кримінального провадження.

Слідчий суддя ухвалює рішення про проведення допиту в режимі ВК за власною ініціативою або на підставі клопотання сторони кримінального провадження у виняткових випадках, пов'язаних із необхідністю отримання показань свідка чи потерпілого під час досудового розслідування, якщо через існування небезпеки для життя і здоров'я свідка чи потерпілого, їх тяжкої хвороби, наявності інших обставин, що можуть унеможливити їх допит у суді або вплинути на повноту чи достовірність свідчень. 
Відповідно до вимог КПК, рішення слідчого та прокурора ухвалюється у формі постанови, яка виноситься у випадках, передбачених КПК, а також коли слідчий, прокурор визнає це за необхідне. Частина 2 ст. 232 КПК передбачає винесення спеціальної постанови (ухвали) про проведення слідчої (розшукової) дії у режимі ВК тільки тоді, коли проти цього заперечує сторона кримінального провадження чи потерпілий. Отже, якщо є заперечення з боку сторони кримінального провадження чи потерпілого щодо проведення слідчої (розшукової) дії у режимі ВК, а слідчий, прокурор чи слідчий суддя вважають за необхідне проводити допит чи впізнання у режимі ВК, то вони повинні обгрунтувати своє рішення у вмотивованій постанові чи ухвалі.

Оскільки для підозрюваного свідчення є правом, а не обов'язком, то проведення слідчої (розшукової) дії за його участю, коли він проти цього заперечує, не допускається.

Деякі особливості має процесуальний порядок проведення слідчих (розшукових) дій у режимі ВК, що відрізняють його від загального порядку проведення зазначених дій. Так, особливості процесуального порядку проведення слідчої (розшукової) дії у режимі ВК залежать від місця перебування особи, яка братиме участь у слідчій (розшуковій) дії за допомогою ВК. Така особа може перебувати: у приміщенні, розташованому на території, яка перебуває під юрисдикцією органу досудового розслідування, або на території міста, в якому він розташований; у приміщенні, розташованому поза територією, яка перебуває під юрисдикцією органу досудового розслідування, або поза територією міста, в якому він розташований.

Учасниками слідчої (розшукової) дії у режимі ВК можуть бути свідки (зокрема й малолітні або неповнолітні), потерпілі, підозрювані. 3 огляду на те, що допит особи і пред'явлення для впізнання осіб чи речей у режимі ВК здійснюються за правилами ст. ст. 225-227 та 228-229 КПК, то у їх проведенні можуть брати участь представник, захисник, спеціаліст, експерт, перекладач, педагог, психолог й інші особи, потреба в яких виникає у зв'язку з особливостями проведення слідчої (розшукової) дії.

Вважаємо, що проведення слідчих (розшукових) дій у режимі ВК не може здійснюватися щодо осіб, що мають дефекти мови, зору чи слуху.

Проведення допиту в режимі ВК за рішенням слідчого судді здійснюється згідно з положеннями ст. 232 КПК та ч. $4-5$ ст. 336 КПК.

Особливість його проведення полягає в тому, що якщо особа, яка братиме участь у процесуальної дії у режимі ВК, перебуває у приміщенні, розташованому на теритоpiï, яка перебуває під юрисдикцією суду, або на території міста, в якому розташований суд, то судовий розпорядник або секретар судового засідання цього суду зобов'язаний перевірити документи, що посвідчують особу, вручити такій особі пам'ятку про її процесуальні права та перебувати поряд із нею до закінчення проведення процесуальної дії.

Якщо особа, яка братиме участь у процесуальної дії у режимі ВК, перебуває в приміщенні, розташованому поза територією юрисдикції суду та поза територією міста, в якому розташований суд, то суд своєю ухвалою може доручити суду, на території юрисдикції якого перебуває така особа, здійснити дії, передбачені ч. 4 ст. 336 КПК. Копія ухвали може бути надіслана електронною поштою, факсимільним або іншим засобом зв'язку. Суд, що отримав доручення, за погодженням із судом, що надав доручення, зобов'язаний у визначений в ухвалі строк організувати виконання зазначеного доручення.

Під час проведення слідчої (розшукової) дії у режимі ВК слід забезпечити належну якість зображення і звуку, а також інформаційну безпеку. Задля цього слідчий, прокурор чи слідчий суддя повинні залучити до участі у проведенні слідчої (розшукової) дії у режимі ВК спеціаліста, який володіє спеціальними знаннями та навичками застосовування відповідних технічних засобів та технологій. Метою залучення спеціаліста $\epsilon$ забезпечення належної якості передання зображення і звуку, безперервного і стабільного сеансу зв'язку та інформаційної безпеки ВК.

КПК не дає визначення термінам «належна якість зображення i звуку» та «інформаційна безпека». Під належною якістю зображення слід розуміти зображення, що дозволяє ідентифікувати особу за його зовнішністю всіма учасниками слідчої (розшукової) дії і зафіксувати це зображення технічними засобами 3 подальшою можливістю ідентифікації учасника слідчої (розшукової) дії за зображенням. Під належною якістю звуку слід розуміти звук, який дозволяє чітко і розбірливо розрізняти свідчення особи за ії голосом всіма учасниками слідчої (розшукової) дії і зафіксувати його технічними засобами з подальшою можливістю ідентифікації учасника слідчої (розшукової) дії за його голосом.

Відповідно до Закону України «Про телекомунікації» від 18.11.2003 р., під «інформаційною безпекою телекомунікаційних мереж» слід розуміти здатність останніх «забезпечувати захист від знищення, перекручення, блокування інформації, іiі несанкціонованого витоку або від порушення встановленого порядку іiї маршрутизації» [2]. Отже, під інформаційною безпекою слід розуміти здатність технічних засобів і технологій забезпечувати захист від знищення, перекручення, блокування інформації, іiі несанкціонованого витоку або від порушення встановленого порядку її маршрутизації.

Перед початком проведення слідчої (розшукової) дії у режимі ВК необхідно переконатися, що ніщо не перешкоджає особі вільно свідчити, заявляти клопотання, надавати докази, що дозволяє уникнути так званого «впливу поза кадром». Проведення слідчої (розшукової) дії в режимі ВК має бути організоване таким чином, щоб було видно не тільки ії учасників, але і все приміщення, у якому воно здійснюється, а також усіх осіб, що беруть участь або присутні під час його проведення, 3 метою спостереження за їх реакцією на конкретні свідчення або поставлені питання.

Учасникам слідчої (розшукової) дії повинна бути забезпечена можливість ставити запитання і отримувати відповіді осіб, які беруть участь у слідчій (розшуковій) дії у режимі ВК, реалізовувати інші надані їм процесуальні права та виконувати процесуальні обов'язки, передбачені КПК.

Оскільки (відповідно до ч. 6 ст. 224 КПК) допитувана особа має право використовувати під час допиту власні документи і нотатки, якщо іiі показання пов'язані з будьякими обчисленнями та іншими відомостями, які важко зберегти в пам'яті, то під час допиту в режимі ВК слід забезпечити можливість передання інформації, яка міститься в таких документах та нотатках. Для цього в місці перебування допитуваної особи слід установити сканер, а в місці перебування слідчого, прокурора, слідчого судді та інших учасників слідчої (розшукової) дії - принтер.

Із метою забезпечення безпеки особи вона може бути допитана в режимі ВК $з$ такими змінами зовнішності

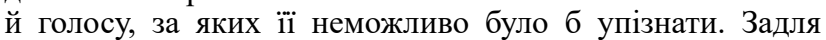
цього застосовуються спеціальні акустичні ефекти, що змінюють голос, а також візуальні перешкоди технічного характеру або іншим чином змінюється зовнішність особи. У такому разі обмін відеоінформацією в режимі ВК не здійснюється, а отримана від допитуваної особи аудіоінформація змінюється за допомогою програмно-апаратних засобів [3].

Слід зауважити, що під час проведення вербальних слідчих (розшукових) дій у режимі ВК знижується рівень комунікативного контакту з його учасником, установлення якого $€$ важливим складником ефективності слідчої (розшукової) дії. Ця обставина зумовлена необхідністю одержання 
особистого, безпосереднього враження від допитуваного та врахування всіх нюансів його поведінки під час давання показань, а також відсутністю: безпосереднього (тобто вічна-віч) спілкування слідчого, прокурора або слідчого судді з учасником слідчої (розшукової) дії; технічною складністю передання всього обсягу інформації; сприятливої для спілкування атмосфери слідчої (розшукової) дії.

Зниження рівня комунікативного контакту під час проведення слідчих (розшукових) дій у режимі ВК не слід розглядати як суттєву перешкоду для використання в кримінальному провадженні ВК. Уважаємо, що ВК слід розглядати як «технічного посередника» між слідчим, прокурором, слідчим суддею, з одного боку, і допитуваним - 3 іншого. ВК передбачає мінімальний вплив на безпосереднє враження від допитуваного, не створює нездоланного бар'єра для ефективної комунікації між учасниками слідчої (розшукової) дії.

У ч. 1 ст. 104 КПК зазначається, що у випадках, передбачених КПК, перебіг і результати проведення процесуальної дії фіксуються у протоколі. Стаття 232 КПК не містить прямої вказівки щодо фіксації перебігу і результатів допиту, проведеного у режимі ВК, у протоколі. Водночас у КПК $є$ низка непрямих указівок, які свідчать про необхідність складання протоколу допиту, проведеного в режимі ВК, а саме: ч. 2 ст. 104 КПК передбачає, що текст показань може не вноситися до відповідного протоколу, якщо допит фіксувався за допомогою технічних засобів. У такому разі в протоколі зазначається, що показання зафіксовані на носії інформації, який додається до нього; п. 3 ч. 2 ст. 105 КПК передбачає, що додатком до протоколу $є$ відеозапис процесуальної дії, який долучається до нього; ч. 5 ст. 224 КПК передбачає, що під час допиту може застосовуватися відеозапис. Отже, під час проведення допиту в режимі ВК має складатися протокол.

Частина 9 ст. 232 КПК передбачає, що перебіг і результати слідчої (розшукової) дії, проведеної у режимі ВК, дає змогу одержати певну фіксовану форму за допомогою технічних засобів відеозапису. Технічні засоби відеозапису перебігу і результатів слідчої (розшукової) дій - це сукупність програмно-апаратних засобів та приладів, що забезпечують належне фіксування, зберігання, копіювання (дублювання) і використання інформації, яка відображає процес ВК [3]. Відео- та аудіозаписи, створені безпосередньо під час проведення ВК та записані за допомогою технічних засобів відеозапису, є вихідним матеріалом для виготовлення робочої та архівної копій.

У матеріалах кримінального провадження обов'язково зберігаються оригінальні примірники технічних носіїв інформації зафіксованої процесуальної дії, резервні копії яких зберігаються окремо.

Відповідно до ч. 6 ст. 107 КПК, незастосування технічних засобів фіксування кримінального провадження у випадках, якщо воно $є$ обов'язковим, тягне за собою недійсність відповідної процесуальної дії та отриманих внаслідок її вчинення результатів.

Висновки. ВК майже не впливає на дію загальних засад кримінального провадження, зокрема й на засади змагальності та безпосередності. Одержання доказів за допомогою ВК може бути альтернативою, яка дозволяє суду, прокуророві або слідчому безпосередньо спостерігати за поведінкою учасника процесуальної дії, його емоціями, жестами, виразом обличчя, голосом, реакцією на поставлені питання, тобто враховувати всю повноту факторів, що впливають на оцінку показань, дозволяє суду безпосередньо заслуховувати показання допитуваного, що, безумовно, сприяє більш ретельному і повному встановленню обставин учиненого кримінального правопорушення, на відміну від одержання доказів за допомогою виконання доручення про провадження процесуальної дії, де вимога про безпосередність дослідження доказів не реалізується зовсім.
Використання ВК як заходу безпеки може бути пов'язане 3 обмеженням процесуальних гарантій, прав інших учасників кримінального провадження. Зважаючи на це, вважаємо за необхідне звернути увагу на таке: використання розглянутого процесуального заходу безпеки у кримінальному провадженні за дотримання певних умов $є$ сумісним із засадою безпосередності дослідження доказів і правом підозрюваного (обвинувачуваного) на захист; проведення допиту в режимі ВК в умовах, що виключають ідентифікацію особи, $є$ допустимим, якщо зі справжніми даними особи, щодо якої здійснюється захист, під час досудового розслідування або судового розгляду можуть ознайомитися прокурор, що здійснює нагляд за додержанням законів, і суд; показання анонімних свідків мають бути отримані судом із дотриманням засади змагальності. Обвинувачуваний (підсудний) при цьому повинен мати можливість бути присутнім на допиті і спостерігати за поведінкою свідка. Недотримання цього порядку $є$ порушенням права конфронтації, передбаченого п. «d» ч. 3 ст. 6 Конвенції про захист прав людини й основоположних свобод від 04.11.1950 p. [4] Надання обвинувачуваному можливості ставити питання анонімним свідкам у письмовий формі через суддю є недостатньою мірою для забезпечення права обвинувачуваного на допит; обгрунтування обвинувачення виключно на показаннях анонімних свідків $є$ недопустимим. Вони повинні бути підтверджені іншими доказами; показання анонімного свідка підлягають ретельній перевірці; рішення про проведення допиту в режимі ВК в умовах, що виключають ідентифікацію свідка, потерпілого, іншого учасника процесу, має бути обгрунтованим. Якщо менш обмежувального заходу буде достатньо, то саме він має застосовуватися (так званий «пріоритет менш обмежувальних заходів»).

Перед початком проведення слідчої (розшукової) дії або судового засідання за допомогою ВК необхідно переконатися, що ніщо не перешкоджає особі вільно свідчити, заявляти клопотання, надавати докази тощо. Ця обставина має суттєве значення для допустимого використання в кримінальному провадженні доказів, отриманих за допомогою ВК. Проведення слідчої (розшукової) дії або судового засідання шляхом ВК має бути організоване таким чином, щоб було видно не тільки його учасників, але і все приміщення, у якому воно здійснюється, а також усіх осіб, що беруть участь або присутні під час його проведення, 3 метою спостереження за їх реакцією на конкретні показання або поставлені питання. Учасникам кримінального провадження має бути забезпечена можливість чути та бачити перебіг судового провадження, ставити запитання й отримувати відповіді, реалізовувати інші надані їм процесуальні права та виконувати процесуальні обов'язки, передбачені КПК.

Особливості проведення допиту за допомогою ВК у сфері міжнародної правової допомоги полягають у такому: допит за допомогою ВК може бути проведений за наявності підстав, передбачених міжнародними договорами та КПК, а також певних обставин, коли внаслідок об'єктивних або суб'єктивних причин не можна одержати показання традиційним способом; допит за допомогою ВК здійснюється для запитуючої держави в режимі «реального часу»; ВК дозволяє посадовим особам компетентного органу запитуючої держави безпосередньо проводити допит із дотриманням законодавства цієї держави, фізично не перетинаючи кордони держави, за умов дотримання суверенітету і територіальної цілісності останньої; проведення допиту у режимі ВК повинно бути організовано таким чином, щоб виключити можливість визнання отриманих доказів недопустимими через певний вплив на допитуваного з боку присутніх осіб під час проведення процесуальної дії (так званий «вплив поза кадром»); під час проведення допиту за допомогою ВК деякі особли- 
вості має тактика проведення допиту, зокрема встановлення психологічного контакту з допитуваною особою. Тому використання ВК вимагає особливої тактики проведення процесуальних дій; ВК є свого роду посередником, проміжною ланкою між судом (прокурором, слідчим), наділеним обов'язком безпосереднього сприйняття доказів і першоджерелом доказів; має свої особливості процесуальне оформлення перебігу і результатів допиту, проведеного за допомогою ВК. Допит за допомогою ВК має супроводжуватися відеозаписом, який є самостійною формою закріплення доказів разом із протоколюванням.

Проведення запитуваних процесуальних дій у режимі ВК забезпечує обвинувачуваному, потерпілому та іншим учасникам можливість під час досудового розслідування або судового розгляду (за умови дотримання змагальності) висловлюватися 3 розглянутих питань, наводити доводи для спростування висновків протилежної сторони, надавати докази та заявляти клопотання.
Переваги одержання показань від осіб, які тримаються під вартою або відбувають покарання в іноземній державі, за допомогою ВК (порівняно з традиційними способами ïx одержання) полягають у такому: безпека організації їх охорони та конвоювання, оскільки знижується ризик можливої втечі, особливо, коли це стосується ув'язнених (засуджених), що перебувають під посиленою охороною; вирішення проблеми транзиту зазначених осіб через територію третіх держав, коли між запитуючою і запитуваною державами відсутні прямі шляхи сполучення; економія витрат $з$ доставки таких осіб до місця проведення процесуальної дії; вирішення проблеми прохань, що збігаються за часом, двох і більше запитуючих держав про тимчасове передання особи, що утримується під вартою на території запитуваної держави для проведення за іії участю процесуальних дій; стосовно осіб, що тримаються під вартою, суттєво скорочується проміжок часу між скоєнням злочину і моментом покарання винуватої особи.

\section{ЛITEPATYPA}

1. Європейська конвенція про взаємну допомогу у кримінальних справах від 20.04.1959. URL: https://zakon.rada.gov.ua/laws/ show/995 036.

2. Про телекомунікації : Закон України від 18.11.2003 р. № 1280-IV. URL: https://zakon.rada.gov.ua/laws/show/1280-15.

3. Інструкції про порядок роботи з технічними засобами відеозапису ходу і результатів процесуальних дій, проведених у режимі відеоконференції під час судового засідання (кримінального провадження) : затв. наказом Державної судової адміністрації України від 15.11.2012 p. № 155. URL: https://zakon.rada.gov.ua/rada/show/v0155750-12.

4. Конвенція про захист прав людини і основоположних свобод від 04.11.1950р. URL: https://zakon.rada.gov.ua/laws/show/995_004. 